Journal of Animal and Veterinary Advances 11 (9): 1362-1367, 2012

ISSN: $1680-5593$

(C) Medwell Journals, 2012

\title{
Study on Bovine Mammary Specific Expression Vector of Expressing Human Lysozyme Gene
}

\author{
${ }^{1}$ Liu Ruo-Yu, ${ }^{1}$ Tian Tian, ${ }^{2}$ Liu Shi-Hui, ${ }^{3}$ Huang Bo, ${ }^{1}$ Zhang Yi-Yu and ${ }^{1}$ Hui Yan-Ting \\ ${ }^{1}$ Key Laboratory of Animal Genetics, \\ Breeding and Reproduction in the Plateau Moutainous Region, Ministry of Education, \\ ${ }^{2}$ College of Life Sciences, Guizhou University, 550025 Guiyang, China \\ ${ }^{3}$ Guizhou Animal Husbandry and Veterinary Research Institute, 550005 Guiyang, China
}

\begin{abstract}
To study the bovine mammary gland bioreactor, the $5^{\prime}$ and 3 ' flanking sequence of bovine $\beta$-casein (CSN2) gene were cloned and connected to the eukaryotic expression vector of pC DNA3.0 which had been modified. The human Lysozyme gene ( $h L Y Z$ ) was inserted into the site between $5^{\prime}$ and $3^{\prime}$ flanking sequence after the vector named $\mathrm{pC}$ was identified and formed the vector named as $\mathrm{pC}-\mathrm{hLYZ}$ subsequently. To determine whether the constructed vector could drive the $\mathrm{hLYZ}$ expression, the $\mathrm{pC}-\mathrm{hLYZ}$ and positive control $\mathrm{hLYZ}$ plasmid were wrapped by the PEI and injected into lactation rabbits through mammary gland centre duct. Milk was collected and the expression status was detected after $72 \mathrm{~h}$. The plate inhibition assay showed that pC$\mathrm{hLYZ}$ eukaryotic expression vector could be a good driver for $h L Y Z$ gene expression in rabbit mammary gland. The results demonstrated that the bovine mammary gland specific expression vector of $h L Y Z$ had been constructed successfully. The establishment of the vector laid the foundation for further study of bovine mammary gland expression technology.
\end{abstract}

Key words: CSN2, hLYZ, Clone, Mammary gland specific expression, bovine, rabbit

\section{INTRODUCTION}

Lysozyme (LYZ) was a kind of non-specificity defenses factor which existed in human and animal's body fluids or tissues widely (Fokunang et al., 2005; Idenyi et al., 2006; Sharifi-Yyazdi et al., 2007; Anand et al., 2010; Han et al., 2011). The LYZ was usually used in clinical and food industries result from the significant pharmacological effects such as anti-bacterial, eases pain, anti-virus, anti-tumor and enhance immune system (Rong and Ling, 1999; Yu et al., 2009; Maga and Murray, 1995). LYZ was main obtained from chicken egg white which own high levels of LYZ (3-4 $\mathrm{mg} \mathrm{mL}^{-1}$ ). However, the activity was only $1 / 3$ of $\mathrm{hLYZ}$ and may even elicit immune response like allergic reaction when used in human being ( $Z$ hu and Sun, 2006).

The natural LYZ can be collected from human milk, placental extract or saliva but very limited (Sun et al., 2004). Therefore, LYZ was considered as one of the main nutritional differences between human and animal milk and it was also the main object about to research animal milk more like human milk (Maga and Murray, 1995). Many studies showed that animal breast tissue was the most ideal place for the expression of transgenic exogenous medical protein although many expression systems had been constructed (Yang et al., 2008). It produced medical protein with the ability of high output and low cost, the protein was processed and modified after translation and also easy to be separated (Shi et al., 2008). At present, the animal mammary gland bioreactor possess the fastest research progress and the best development perspective. The basic principle is that the target gene with important development value will be fused with the regulatory sequence of lactoprotein gene to construct the mammary gland specific expression genetic component.

Subsequently, it is injected into the animal embryos to obtain the transgenic offspring. When the animals lactating, the exogenous gene will express under the control of lactotropin and the regulatory sequence of lactoprotein gene, the expression level can meet or exceed the normal content of lactoprotein (Archibald et al., 1990). Therefore, these transgenic animal breasts are like natural factories of producing activity protein and we can collect the valuable bioactive protein constantly as long as the animals are fed. In this study, we constructed the bovine mammary gland expressing vector of $\mathrm{hLYZ}$ and detected the foundation to expressed $\mathrm{hLYZ}$ for exploring the feasibility of bovine mammary gland expressing $\mathrm{hLYZ}$.

Corresponding Author: Liu Ruo-Yu, Key Laboratory of Animal Genetics,

Breeding and Reproduction in the Plateau Moutainous Region, Ministry of Education, Guizhou University, 550025 Guiyang, China 
Table 1: The three pairs of primer sequences for PCR amplification

\begin{tabular}{llcc}
\hline Primers & Primer sequences $\left(5^{\prime} \rightarrow 3^{\prime}\right)$ & Product size/kb & Annealing temp. $\left({ }^{\circ} \mathrm{C}\right)$ \\
\hline CSN2-5' & F: AGTCGCGAATTGCTGGCTTTTAAATTTTCCCT & 1.8 & 59 \\
& R: ATGGTACCACGCGTAAGGAGGAGCTGAATGGATAATGA & & 5 \\
CSN2-3' & F: CTGGTACCTAAGCTTTAGGAGATTAGAGGC & 1.1 & 55 \\
& R: ATCTCGAGATGCCTAAGGGTTAATTTATTG & & \\
hLYZ & F: ATACGCGTATGAAGGCTCTCATTGTTCTGGGGCT & 1.5 & 57 \\
& R: CTGGTACCGTGTTGCAAAGCCTTAATTAGAATG & & \\
\hline
\end{tabular}

NruI, TCGCGA; KpnI, GGTACC; MluI, ACGCGT; XhoI, CTCGAG

\section{MATERIALS AND METHODS}

Plasmid, host cell and animals: Eukaryotic expression vector pC DNA3.0, vector pMD19-T and DH5 $\alpha$ were purchased from TaKaRa (Dalian, China). The cDNA of $\mathrm{hLYZ}$ was synthesized by Heng Yin Biotech (Shanghai). The experimental rabbits ( 20 individuals) were reared in the same management system in XinMin rabbit company located in Guizhou, Guiyang, P.R. China.

Primers design and PCR amplification: According to the sequence of CSN2 gene (GenBank No.: AY352050) and part of $h L Y Z$ gene (GenBank No.: NC_000012.11), three pairs primers to make Restriction Endonuclease Analysis (REA) were designed using the primer 5.0 Software (Table 1).

The $25 \mu \mathrm{L}$ volume of PCR amplification contained: 100 ng genomic DNA, $0.5 \mu \mathrm{M}$ each primer, $1 \times$ buffer (including $1.5 \mathrm{mM} \mathrm{MgCl}_{2}$ ), $200 \mu \mathrm{M}$ dNTPs and 1 units of Taq DNA polymerase (MBI, Fermentas). The PCR cycling conditions consisted of an initial single cycle for $10 \mathrm{~min}$ at $95^{\circ} \mathrm{C}$ followed by 35 cycles of cycling consisting of $94^{\circ} \mathrm{C}$ for $60 \mathrm{sec}$, annealing for $60 \mathrm{sec}$ and $72^{\circ} \mathrm{C}$ for $90 \mathrm{sec}$ with a final extension at $72^{\circ} \mathrm{C}$ for $10 \mathrm{~min}$.

The PCR fragments of three pairs primers were cloned into the pMD19-T vector (Takara, China) and then sequenced for confirmation in both directions, respectively. All the sequences were compared with the published sequence in GenBank by using the Blast search program at the NCBI website.

Expression vector construction: Restriction enzyme PvuI was used to treat the pC DNA3.0 vector and transformed DH5á competent cells, then the plasmids were extracted and named as pA. pA and CSN2 gene 5'-pMD19-T vector were cutting by using restriction enzyme Nru I+Kpn I to obtain cohesive end $\mathrm{pA}$ and CSN2-5' flanking, respectively and connected their with $\mathrm{T} 4$ ligase and transformed $\mathrm{DH} 5 \alpha$ competent cells and then extracted the plasmids and named it as $\mathrm{pB}$. In order to get cohesive end CSN2-3' flanking and $\mathrm{pB}$, Xho I+Kpn I were used to cut CSN2 gene 5'-pMD19-T vector and $\mathrm{pB}$, then linked their with T4 ligase and names as $\mathrm{pC}$. pC was digested by Mlu I and sticky end fill flat using Klenow fragment to obtain pC-hLYZ. All productions were identified by enzyme digestion and PCR amplification.

hLYZ transient expression in rabbits mammary gland: The healthy adult rabbits which obtained one day ago were utilized as laboratory animals. The $\mathrm{pC}-\mathrm{hL} \mathrm{YZ}$ vector and the positive vector were wrapped by PEI and 5\% glucose solution, respectively.

Experimental animals were allotted to experimental groups and control group randomly, the experimental groups were injected with recombinant plasmid of different doses.

The doses were $100 \mu \mathrm{L}$ (50 $\mu \mathrm{g}$ plasmid), $200 \mu \mathrm{L}$ (100 $\mu$ g plasmid), $400 \mu \mathrm{L}(200 \mu \mathrm{g}$ plasmid $), 500 \mu \mathrm{L}(250 \mu \mathrm{g}$ plasmid) and $600 \mu \mathrm{L}$ (300 $\mu \mathrm{g}$ plasmid), respectively. The control group was injected with blank vector, repeated injection after $24 \mathrm{~h}$. The milk were collected after $48 \mathrm{~h}$ and tested the effect of $\mathrm{hLYZ}$.

Statistical analysis: All data were analysed by Excel 2007 (Microsoft, USA).

\section{RESULTS AND DISCUSSION}

PCR amplification: After the 30 cycles PCR amplification for the 5 ' and 3 ' flanking sequence of CSN2 gene and the sequence of $h L Y Z$ gene, researchers obtained $2 \mu \mathrm{L}$ production of the PCR extension reaction to run agarose gel electrophoresis and stain by EB then the sizes were $1.8,1.1$ and $1.5 \mathrm{~kb}$, respectively which matched the initial anticipation (Fig. 1 and 2).

Identification of the $C S N 2$ gene and hLYZ-T vector: The CSN2 5'UTR-T vector was cut by using the enzymes NruI and $\mathrm{KpnI}$, the sequences were about 1.8 and $2.7 \mathrm{~kb}$ (Fig. 3). The CSN2 3'UTR-T vector was cut by XhoI and $\mathrm{KpnI}$ then the sequences were 2.7 and $1.1 \mathrm{~kb}$ (Fig. 4). Furthermore, the hLYZ-T was cut by KpnI and MluI and the sequences were 1.5 and $2.7 \mathrm{~kb}$. It showed that the sizes were same as the expected ones. 


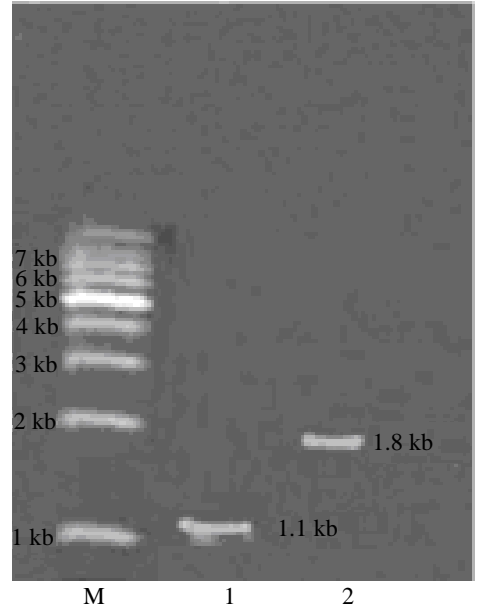

Fig. 1: PCR production of CSN2 gene $5^{\prime}$ and $3^{\prime}$ lanking sequence. Lane M: $1 \mathrm{~kb}$ DNA landder (TIANGEN), Lane 1: PCR production of CSN2 3'UTR; Lane 2: PCR production of CSN2 5'UTR

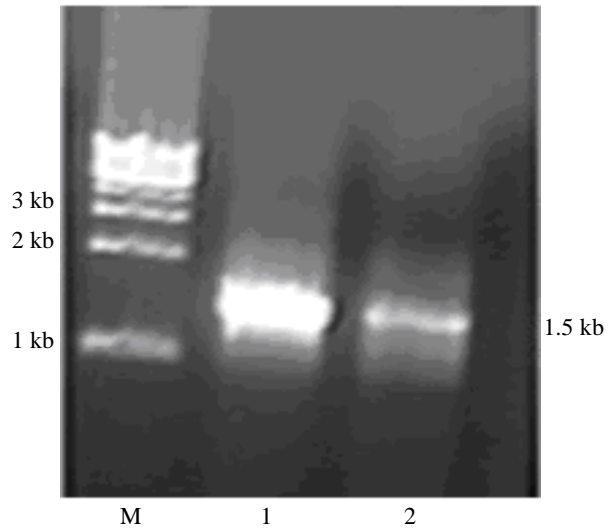

Fig. 2: PCR production of $\mathrm{hLYZ}$. Lane M: $1 \mathrm{~kb}$ DNA landder (TIANGEN); Lane 1, 2: PCR production of hLYZ

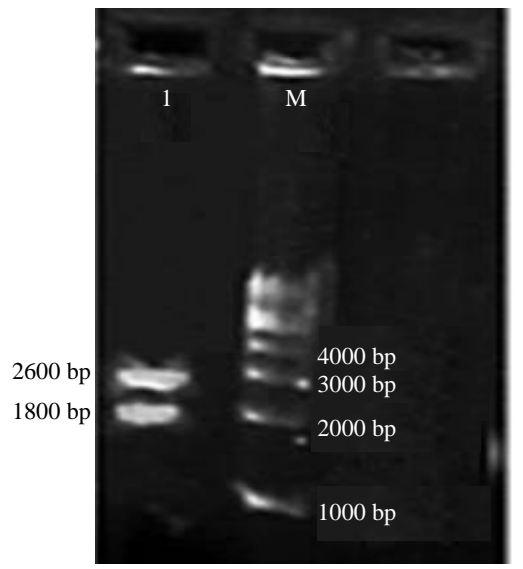

Fig. 3: Identification of CSN2 5'-portion-T vector Lane M: $1 \mathrm{~kb}$ DNA landder (TIANGEN), Lane 1: NruI+KpnI cutting of CSN2 5'UTR-T vector

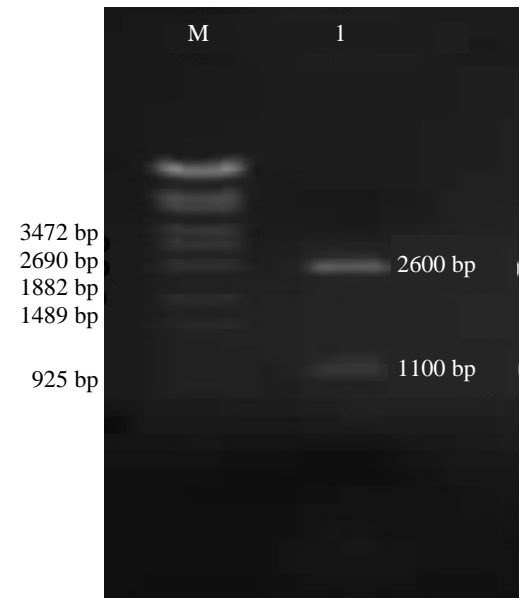

Fig. 4: Identification of CSN2 3'-portion-T vector. Lane M: $\lambda$-EcoT1 4digest DNA Marke (TIANGEN), Lane 1: XhoI+KpnI cutting of PSP-II 3'UTR-T vector

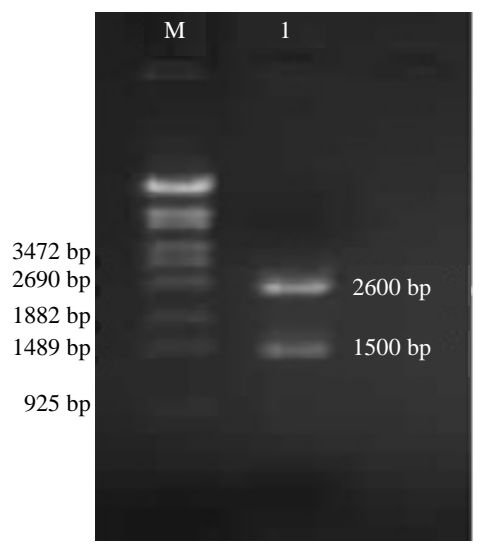

Fig. 5: Identification of $\mathrm{hLYZ}-\mathrm{T}$ vector. Lane $\mathrm{M}$ : $\lambda$-EcoT1 4digest DNA Marke (TIANGEN), Lane 1 : XhoI $+\mathrm{KpnI}$ cutting of $\mathrm{hL} Y \mathrm{YZ}-\mathrm{T}$ vector

Construction of bovine mammary specific expression vector of expressing human lysozyme gene: The $5^{\prime}$ and $3^{\prime}$ flanking sequence of $C S N 2$ gene and $h L Y Z$ gene were cloned into the pC DNA3.0 vector which have been reformed then identified by enzyme digestion and PCR. The results showed that $\mathrm{pB}$ was $4.4 \mathrm{~kb}, \mathrm{pC}$ was $5.5 \mathrm{~kb}$ and pC-hLYZ was $6.9 \mathrm{~kb}$ and they also agreed with the outcome of anticipation (Fig. 4-8)

Transient expression in rabbit mammary gland: The $\mathrm{pC}-$ $h L Y Z$ vectors with different doses were injected into the rabbits' mammary gland which had been wrapped by PEI. The milk were collected after $48 \mathrm{~h}$ of injection and the in vitro drug sensitive test was used to investigate the effect, at last we discovered the bacteriostasis. There were mild bacteriostasis to Staphylococcus aureus with $50 \mu \mathrm{g}$ 


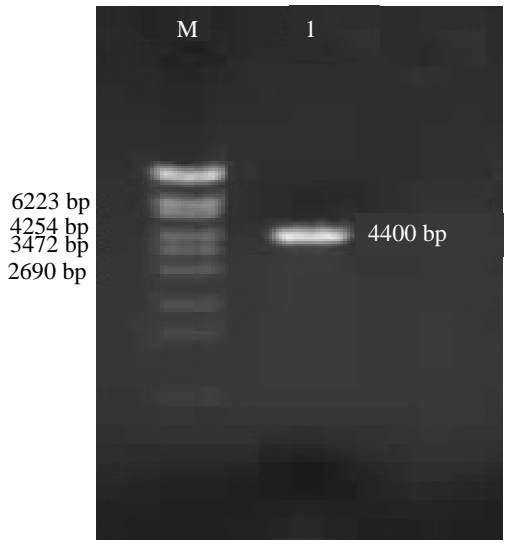

Fig. 6: Identification of $\mathrm{pB}$ vector. Lane $\mathrm{M}$. $\lambda$-EcoT14digest DNA Marker (TIANGEN), Lane 1:

$\mathrm{NruI}+\mathrm{KpnI}$ cutting of $\mathrm{pB}$ vector

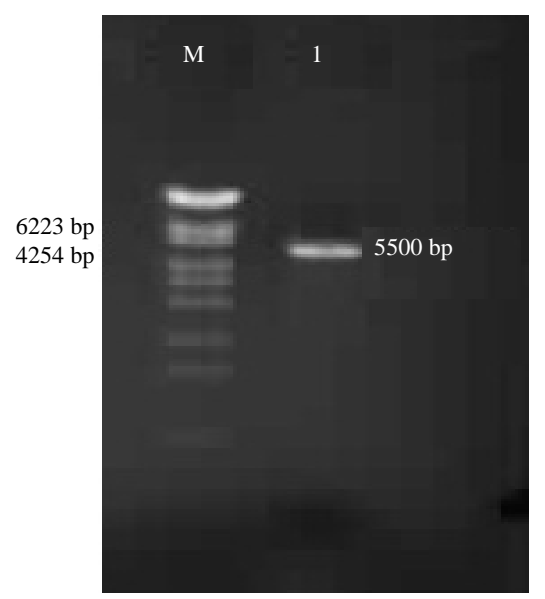

Fig. 7: Identification of $\mathrm{pB}$ vector. Lane $\mathrm{M}$ : $\lambda$-EcoT14digest DNA Marker (TIANGEN), Lane 1: $\mathrm{NruI}+\mathrm{KpnI}$ cutting of $\mathrm{pC}$ vector

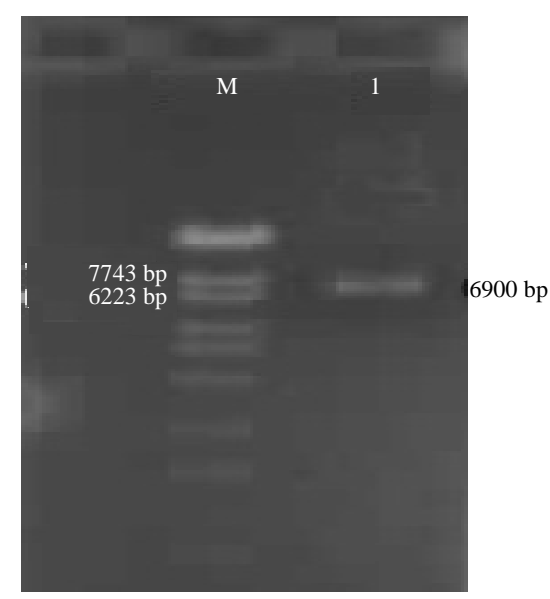

Fig. 8: Identification of $\mathrm{pC}-\mathrm{hLYZ}$ vector. Lane 1: MluI cutting of $\mathrm{pC}$ VectorfpC-hLYZ vector, Lane $\mathrm{M}$ : $\lambda$-EcoT14digest DNA Marker (TIANGEN)

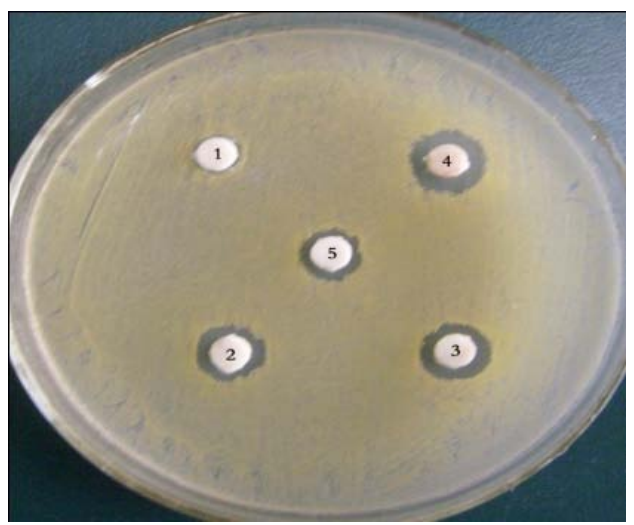

Fig. 9: hLYZ inhibition of Staphylococcus aureus test results; 1) Injection $\mathrm{pC}-\mathrm{hL} Y Z$ of 50 ug; 2) Injection pC-hLYZ of 100 ug; 3) Injection pC-hLYZ of $200 \mathrm{ug}$; 4) Injection pC-hLYZ of 300 ug; 5) Penicillin group $500 \mathrm{IU}$

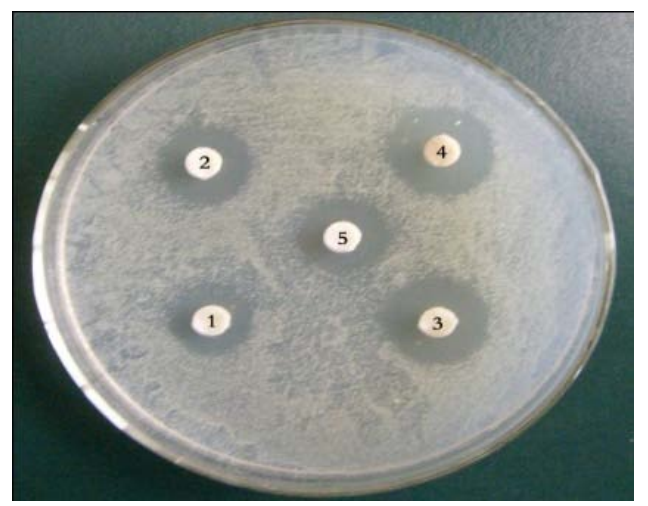

Fig. 10: hLYZ inhibition of Streptococcus agalactial test results; 1) Injection $\mathrm{pC}-\mathrm{hLYZ}$ of $50 \mathrm{ug} ; 2$ ) Injection pC-hLYZ of 100 ug; 3) Injection pC-hLYZ of 200 ug; 4) Injection pC-hLYZ of 300 ug; 5) Penicillin group $500 \mathrm{IU}$

dose of vector and the bacteriostasis was better when the dose was $200 \mu \mathrm{g}$. However, the inhibition zone had no emarkable increase when injected with $300 \mu \mathrm{g}$ recombinant plasmid compared with the dose of $200 \mu \mathrm{g}$. the mammary gland showed necrosis and milk could not be collected when the injection reached $400 \mu \mathrm{g}$ time $^{-1}$.

Moreover, the same results obtained when studied the bacteriostasis to Streptococcus agalactiae. The blank control didn't show bacteriostasis to the two bacterium (Fig. 9-11).

Content of transient expression hlyz in rabbit milk: Bacteriostasis significance was represented by the width of inhibition zone (W) (Zhang et al., 2004): 


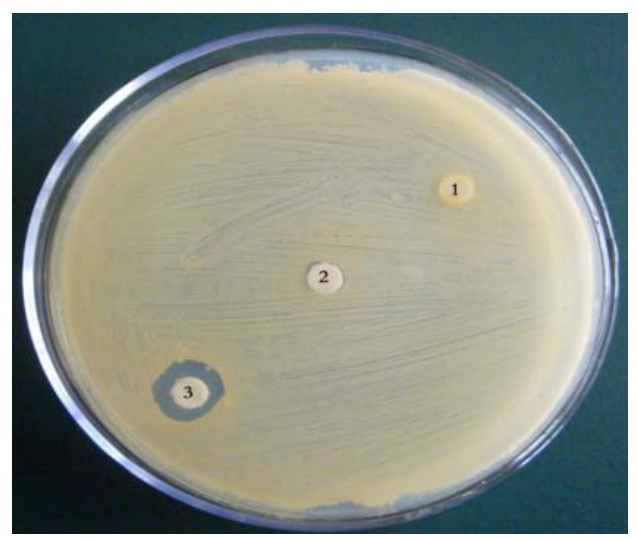

Fig. 11: Antibacterial test results of the control group; 1) Control group; 2) Injection pC-hLYZ of $50 \mathrm{ug}$; 3) Penicillin group $500 \mathrm{IU}$

Table 2: Human lysozyme against Stophylococcus cureus and Streptococcus agalactice of antibacterial cativity Staphylococcus cureus Streptococcu agalactiae $\left.2.28 \times 10^{7} \mathrm{CFU} \mathrm{mL}^{-1}\right) \quad\left(5.32 \times 10^{6} \mathrm{CFU} \mathrm{mL}^{-1}\right)$

\begin{tabular}{lcccccc}
$\begin{array}{l}\text { Dose } \\
\left(\mu \mathrm{g} \mathrm{time}^{-1}\right)\end{array}$ & $\mathrm{D}(\mathrm{mm})$ & $\mathrm{W}(\mathrm{mm})$ & $\begin{array}{c}\text { Bacter- } \\
\text { iostasis }\end{array}$ & $\mathrm{D}(\mathrm{mm})$ & $\mathrm{W}(\mathrm{mm})$ & $\begin{array}{c}\text { Bacter- } \\
\text { iostasis }\end{array}$ \\
\hline 50 & 7.50 & 0.75 & - & 13.25 & 3.63 & +++ \\
100 & 9.50 & 1.75 & + & 15.50 & 4.75 & +++ \\
200 & 10.25 & 2.13 & + & 17.25 & 5.63 & +++ \\
300 & 10.35 & 2.18 & + & 17.75 & 5.88 & +++ \\
400 & -- & - & -- & - & - & -- \\
$500 \mathrm{IU}$ penicillin & 8.25 & 1.13 & + & 14.25 & 4.13 & ++
\end{tabular}
(control)

--: Did not collect the milk; ++: $\mathrm{W}>3 \mathrm{~mm}$, the inhibition effect was strong; ++: $2.5<\mathrm{W}<3.0 \mathrm{~mm}$, the inhibition effect was middle; +: 1 $\mathrm{mm}<\mathrm{W}<2.5 \mathrm{~mm}$, inhibition; -: $\mathrm{W}<0.9 \mathrm{~mm}$, weak or no inhibition

$$
\mathrm{W}=\frac{\mathrm{D}-\mathrm{d}}{2}
$$

Where:

$$
\begin{aligned}
& \mathrm{W}=\text { Width of inhibition zone } \\
& \mathrm{D}=\text { Diameter of inhibition zone } \\
& \mathrm{d}=\text { Diameter of the paper }(6 \mathrm{~mm})(\text { Table } 2)
\end{aligned}
$$

The mammary specific expression vector of expressing $h L Y Z$ gene was constructed by using CSN2 gene regulatory sequences which contained the $5^{\prime}(1.8 \mathrm{~kb})$ and $3^{\prime}(1.1 \mathrm{~kb})$ flanking sequence (it contained part of the last intron and the last untranslated extron), the 3 ' flanking sequence contained polyA and $\mathrm{G} / \mathrm{T}$ group, these sequences played an important part in mRNA transcription and the stability of cytoplasm translation regulation. More importantly, they possess the obvious interreaction chronically result in the endogenous transcription of CSN2 under the induction of reasonable factor (hormone). Researchers cloned the pC DNA3.0 vector which contained the $5^{\prime}$ and $3^{\prime}$ flanking sequence of CSN2 gene and the cDNA of $h L Y Z$ gene then the mammary specific expression vector $\mathrm{pC}-\mathrm{hL} \mathrm{YZ}$ was constructed. In this specific expression vector the structural gene of CSN2 was replaced by the cDNA of $\mathrm{hLYZ}$ and based on the endogenous expression regulation style. If the expression vector's integration site is suitable, it will drive the expression of exogenous target gene in mammary gland epithelial cells and tissue.

The successful construction of $\mathrm{pC}-\mathrm{hLYZ}$ vector laid the foundation for the regulation mechanism and regulation characteristic of the 5 ' and 3 ' flanking sequence of CSN2 gene. However, the expression quantity of pC$\mathrm{hLYZ}$ vector, the mechanism and characteristic of the $5^{\prime}$ and 3 ' flanking sequence of CSN2 gene even whether there is hormonal dependency element are all need further study (Liu et al., 2004).

pC-hLYZ were wrapped by PEI and injected into rabbit's mammary gland and the dose were $100 \mu \mathrm{L}(50 \mu \mathrm{g}$ plasmid), $200 \mu \mathrm{L}$ (100 $\mu$ g plasmid), $400 \mu \mathrm{L}$ (200 $\mu$ g plasmid), $500 \mu \mathrm{L}(300 \mu \mathrm{g}$ plasmid) and $600 \mu \mathrm{L}(400 \mu \mathrm{g}$ plasmid), respectively. This experiment demonstrated that the expression effect was closely related to the volume of plasmid. When the dose was $100 \mu \mathrm{g}$, there was an acceptable effect but the inhibition zone was no longer larger as the dose increased when the dose was $300 \mu \mathrm{g} /$ time. When the injection reached $400 \mu \mathrm{g}$ time $^{-1}$ the mammary gland showed necrosis.

\section{CONCLUSION}

Calcium phosphate precipitation, DEAE-glucan method, electricity wear method and liposomes transfection method are common transient transfection methods (Sambrook and Russell, 2002). Liposomes transfection method is reliable and has good repeatability but it is expensive and need large dosage (Thierry et al., 1997). PEI was found as an effective gene transfection reagent and applied in transgenic study of cellls and mammals widely (Zhang et al., 2000). The plasmids with $\mathrm{hLYZ}$ cDNA were wrapped by PEI transfection to the mammary glands of rabbit and the expression effect was perfect.

\section{ACKNOWLEDGEMENTS}

This research was supposed by the governor special fund of Guizhou Province outstanding science and technology educates talented person (Qian technology office NO. [2007] 03).

\section{REFERENCES}

Anand, P., D. Rajakumar, A.J.W. Felix and T. Balasubramanian, 2010. Effects of oral administration of antioxidant taurine on haematological parameters in wistar rats. Pak. J. Biol. Sci., 13: 785-793. 
Archibald, A.L., M. McClenaghan, V. Hornsey, J.P. Simons and A.J. Clark, 1990. High level expression of biologically active human $\alpha 1$ antitrypsin in the milk of transgenic mice. Proc. Natl. Acad. Sci., 87: 5178-5182.

Fokunang, C.N., K.A. Watson, A. Purvis and E.A. TembeFokunang, 2005. Crystallization and structural studies of lysozyme from hen egg white, using vapour diffusion techniques. Biotechnology, 4: 341-346.

Han, H.B., X. Li, K. Yu, W.Z. Ma, Z.C. Cao, G.F. An and Z.X. Lian, 2011. Egg White Lysozyme Promoted Collagen Secreting of Dermal Fibroblasts in Mice Asian J. Anim. Vet. Adv., 6: 667-677.

Idenyi, N.E., C.E. Ekuma and A.E. Umahi, 2006. Effect of temperature and $\mathrm{ph}$ on the spectral and conformational distribution of adsorbed lysozyme. Biotechnology, 5: 429-435.

Liu, J.L., Y.M. Zheng and Y.J. Wang, 2004. Molecular cloning and sequence analysis of bovine $\beta$-casein gene 5', 3' control region. J. Northwest Sci-Tech. Univ. Agric. For., 2: 99-103.

Maga, E.A. and J.D. Murray, 1995. Mammary gland expression of transgenes and the potential for altering the properties of milk. Nat. Biotechnol., 13: $1452-1457$.

Rong, X.H. and P.X. Ling, 1999. Lysozyme study progression. Chinese J. Biochem. Pharm., 20: 319-320.

Sambrook, J. and D.W. Russell, 2002. Molecular Cloning: A Laboratory Manual. 3rd Edn., Cold Spring Harbor Laboratory Press, USA., ISBN: 7030103386/Q.1163.

Sharifi-Yyazdi, M.K., F. Esmaily, F. Vaezzadeh and H. Dargahi, 2007. Evaluation of outer membrane proteins of Pseudomonas aeruginosa as a protective agent in mice model. Pak. J. Biol. Sci., 10: 4515-4518.
Shi, G.S., J.X. Deng and H.X. Chen, 2008. Advances in control elements of lactoprotein and expressing vector of mammary gland bioreactors. Lett. Biotechnol., 19: 746-749.

Sun, H.C., F. Yu, J.H. Su, C. Wu, Q. Zhang and G.C. Li, 2004. Preliminary studies on gene therapy for dairy cow mastitis using human lysozyme gene. Chinese J. Anim. Vet. Sci., 35: 227-232.

Thierry, A.R., P. Rabinovich, B. Peng, L.C. Mahan, J.L. Bryant and R.C. Gallo, 1997. Characterization of liposome-mediated gene delivery: Expression, stability and pharmacokinetics of plasmid DNA. Gene Ther., 4: 226-237.

Yang, X.F., Y.M. Liu and W.J. Zhang, 2008. Animal mammary gland bioreactor for modern biological pharmaceutical applications. Anim. Sci. Vet. Med., 6: 21-22.

Yu, L.L., C.L. Pan, W.J. Guan and S.Z. Qing, 2009. Application and prospect for animal mammary gland bioreactor. Prog. Mod. Med., 30: 5-7.

Zhang, H.H., A.Y. Qiu and H.J. Liu, 2004. Inhibition of chinese medicine rhubarb extract for several livestock and poultry pathogenic bacterium. Forage Ind., 25: 24-26.

Zhang, M.L., R.L. Hu and X.L. Yu, 2000. Effects of different transfection reagents on genetic immunization of rabies virus glycoprotein cDNA. Chinese J. Vet. Sci., 20: 132-135.

Zhu, Q.J. and H.C. Sun, 2006. Transient expression of human lysozyme in laying hen oviduct. Lett. Biotechnol., 6: 11-12. 